JOURNAL

of Health Inequalities

\title{
The Polish Anti-Tobacco Law in a global context
}

\author{
Mateusz Zatoński \\ London School of Hygiene and Tropical Medicine, London, UK \\ Health Promotion Foundation, Nadarzyn, Poland
}

ADDRESS FOR CORRESPONDENCE: Mateusz Zatoński, London School of Hygiene and Tropical Medicine, Keppel Street, London WC1E 7HT, UK, e-mail: mateusz.zatonski@Ishtm.ac.uk

In its last two issues, the Journal of Health Inequalities has published a series of articles marking the $20^{\text {th }}$ anniversary of the introduction of the Polish Anti-Tobacco Law. Their authors described, amongst others, the history of the Polish anti-tobacco movement [1], the health and social legacy of the Anti-Tobacco Law [2], the broader public health developments in Poland in the 1990s [3], and presented reflections of a health advocate involved in the Polish anti-tobacco movement [4]. Reports from a conference [5] and from a witness seminar [6] on tobacco control in Poland, organised by the Polish Ministry of Health, the Chief Sanitary Inspectorate, and the Health Promotion Foundation, were also published.

In this issue of the Journal of Health Inequalities we would like to present a further set of articles in the series, this time placing Poland's tobacco control achievements in a broader international landscape. The first article is a report from a seminar co-organised by the Harvard University Department of the History of Science and the Health Promotion Foundation, in which a group of international public health experts charted some of the key developments from the past of tobacco control, examined the most pressing present challenges, and hypothesised on the key concerns in years to come (see Report from the seminar on the past, present and future of tobacco control, Harvard University Department of the History of Science, Cambridge, Massachusetts, October 2016, pp. 16-23). The second article outlines the role of the Seventh-day Adventist Church in promoting public health efforts, both in Poland and globally (see Smoking menace still haunting humanity, pp. 24-26). The third article takes this year's World No Tobacco Day, which focused on the role played by tobacco control in achieving sustainable development, as a starting point for a discussion on the relation between effective anti-smoking measures and prosperity (see Tobacco control: an investment that leads to global development, pp. 27-29).

\section{DISCLOSURE}

Author reports no conflict of interest.

\section{References}

1. Zatoński M. Poland's anti-tobacco advocacy - a historical outline. J Health Inequal 2016; 2: 26-31.

2. Zatoński M, Zatoński WA, Przewoźniak K, et al. The significance and impact of the Polish Anti-tobacco Law. J Health Inequal 2016; 2: 32-35.

3. Zatoński WA, Zatoński M. Democracy is healthier - health in Poland in the late 1980s and 1990s. J Health Inequal 2016; 2: 17-24.

4. Thompson S. One American reflects on cigarette promotions in Poland in the 1990s. J Health Inequal 2016; 2: 131-132.

5. Zatoński M. Report from the Conference on Smoke-free Poland, Ministry of Health, Warsaw, Poland, 18 May 2016. J Health Inequal 2016; 2: 111-119.

6. Zatoński M. Report from the witness seminar on tobacco control policy in Poland, Chief Sanitary Inspectorate, Warsaw, Poland, 31 May 2016. J Health Inequal 2016; 2: 120-127. 